\title{
Not all Lockdowns are Created Equal. Indian Migrant Crisis in Times of COVID-I 9
}

\author{
Stany Babu \\ University of Bahrain, Bahrain \\ sbabu@uob.edu.bh
}

\begin{abstract}
The COVID- 19 pandemic in India laid visible the stark disparity and unequal distribution of resources in the Indian society. With the imposition of one of the harshest lockdowns in the world, the migrant workers in the country (both interstate and intrastate) have taken the cruel brunt of this pandemic. These internal migrant workers were left in the urban economic centres (cities) with no proper housing, jobs (most of them being employed in informal sectors) and any form of income generation. This led to a mass exodus of migrant workers from urban centres to their rural homes in the hope that they may not go hungry and will have a roof over their heads. The global crisis brought to the forefront that the pandemic is being experienced differently by different economic strands of the Indian society. By severing the public transportation (buses and trains), to mitigate the risk of spread of the virus across districts and states, the migrant workers were denied the only means of affordable movement. This paper will chronicle the many obstacles and hardships that were faced by the migrants when public transportation was denied, on their long journey 'home', without any certainty of reaching their villages alive.
\end{abstract}

Keywords: migrants, India, public transportation, lockdown, pandemic

To cite this article:

Babu, S. (2020). Not all Lockdowns are Created Equal. Indian Migrant Crisis in Times of COVID19, The Journal of Public Space, 5(3), I05-I I4, DOI 10.3289 I/jps.v5i3.I370

This article has been double blind peer reviewed and accepted for publication in The Journal of Public Space. (C) This work is licensed under a Creative Commons Attribution - Non Commercial 4.0 International License https://creativecommons.org/licenses/by-nc/4.0/ 
"I tried catching a bus or truck yesterday, but there is no transport available on the road, so I decided to walk. It's better to be home than to be here in the city without food and water." - Surendra Pandey, a 28 year old labourer along his $110 \mathrm{~km}$ (68 mile) walk home

(Sharma \& Khanna, 2020)

On 24th of March 2020 the Prime Minister of India Narendra Modi through his 8PM national address declared that the country will be going into a nationwide lockdown, within four hours, for a period of 21 days. Lockdown I.0, as it is now being called, was the first in a series of lockdowns. While this announcement impacted all sections of the society, the crisis was acutely felt by the internal migrant workers whose jobs were informal and contractual (Jan Sahas, 2020, P 6). Soon after the lockdown was declared, the country saw the middleclass man hurrying to supermarkets to stock up on essential goods, while the migrant workers were contemplating a harsher reality on how to survive in a city that had now become a death trap with no proper access to social security, food, housing or income. India has welfare measures for those beyond the poverty lines, but they are not accessible to migrant workers since welfare services are available only in their places of births (Chatterjee, 2020). With strict movement restrictions and public transportation (interstate and intrastate trains and buses) coming to a standstill, the migrant workers were left stranded in a foreign space with no means of getting back to the relative safety of their rural homes. This led to a mass exodus of migrant workers on foot, the only means of transportation available to them. As stated in a letter by 20 senior judges of the Supreme Court of India to the Chief Justice of India, the lockdown and its repercussions felt by the migrant workers led to one of the 'biggest humanitarian crisis in Independent India' (SWAN, 2020, p.I I).

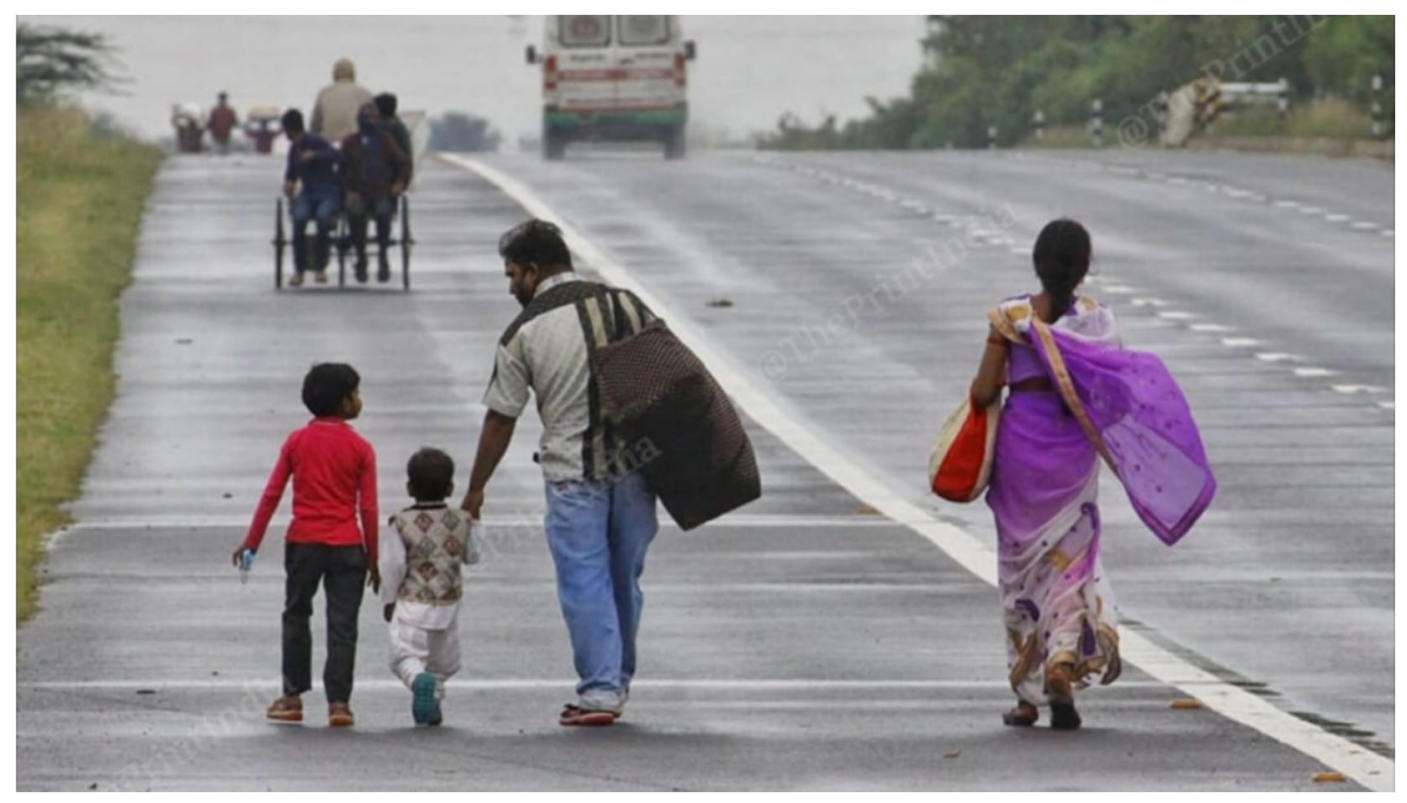

Figure I. Migrant workers trudging along a highway to the Delhi-Ghaziabad border. Photo: Suraj Singh Bisht | ThePrint

The migrant workers in Indian urban centres are the invisible backbone of the economy. They constitute 37\% of the Indian population (Singh, 2020) out of which 65 million are 
interstate migrants (Dharker, 2020) as per the 201 I census. They account for ' $50 \%$ of the national income and constitute a large part of the human capital base of the country' (Ratho \& Bhowmick, 2020). Niti Aayog, the policy think-tank of the Indian Government in their 'Strategy for New India @ 75' stated that 85\% of all workers are employed in the informal sector (Niti Aayog, 2018). 'Faced with social and political anti-migrant attitudes on one hand, and precarious employment opportunities on the other, they live in a state of chronic crisis. 'Rural 'homes' of memories and belonging do not sustain their livelihoods, while cities fail to give them economic security and a sense of belonging' (Kumar \& Das, 2020). According to the World Bank, 'the lockdown in India has impacted the livelihoods of a large proportion of the country's nearly 40 million internal migrants. Around 50,000-60,000 moved from urban centres to rural areas of origin in the span of a few days' (World Bank, 2020, P 2). Public transportation at affordable rates are the only means of movement for the migrant workers who have travelled across the length and width of India to different cities for employment. By curtailing this movement and in the face of an economic shutdown that had rendered them jobless and homeless. the Indian government pushed the migrant workers to a point of desperation.

For the internal migrant workers risk of starvation in the Indian cities was more acute than the virus itself. According to a report titled 'Voices of the Invisible citizens' conducted by the NGO Jan Sahas,

The mass reverse exodus proves that if unable to work, then there is nothing left for a migrant in a city. This shows how in cities, migrants are being reduced merely to their labour power, not considered equal citizens by either the civil society or the state, and thereby denied any social community to fall back on. It is also symptomatic of the exclusion of the migrant population from all social safety mechanisms.

(Jan Sahas, 2020, p. 28)

The day after the announcement of a national lockdown, Mumbai, Chennai, Kolkata and other cities which had drawn the migrants with the economic benefits, saw a mass exodus of more than half a million migrants, the scale of which has not been seen since Indian partition. Migrant workers started walking, cycling and hitchhiking home covering hundreds of kilometres, in some cases covering a distance from the South Indian city of Chennai in Tamil Nadu to a village in the North Eastern state of West Bengal. This was an unprecedented situation that the government had not taken into consideration before calling for a short notice lockdown. There were no proper planning or policies available or introduced to tackle this sudden crisis. This flight of migrants gained international attention as we saw families with young children trekking across highways with little to no food or rest. Many migrants were stopped at their state borders as they had closed interstate movement to curb the spread of the virus. These workers who had walked for kilometres were asked to go back to a place with no job and limited rations. Even when they did reach their rural 'homes' they brought with them the fear of virus spread which led to inhumane acts such as spraying the returning workers with disinfectants causing outrage across and outside the country. A stark contrast was drawn showcasing the citizens shuttled back from foreign countries through free flights to their 'home' country, while migrant citizens within the country were left to their own devices on surviving the pandemic. While the rich and middle 
class were lamenting the inconvenience of being cooped up within their homes, the ground situation for the migrants was one of survival. Many started crowding near railway stations, which had halted all trains, and in desperation even hid inside essential goods trucks. 'Workers state that while they are aware of the dangerous implications of their actions in the event of a lockdown, they are forced to make a choice between their safety and hunger. Based on reports from media articles, labourers were stranded on borders with no water or food' (Jan Sahas, 2020, p. 19).

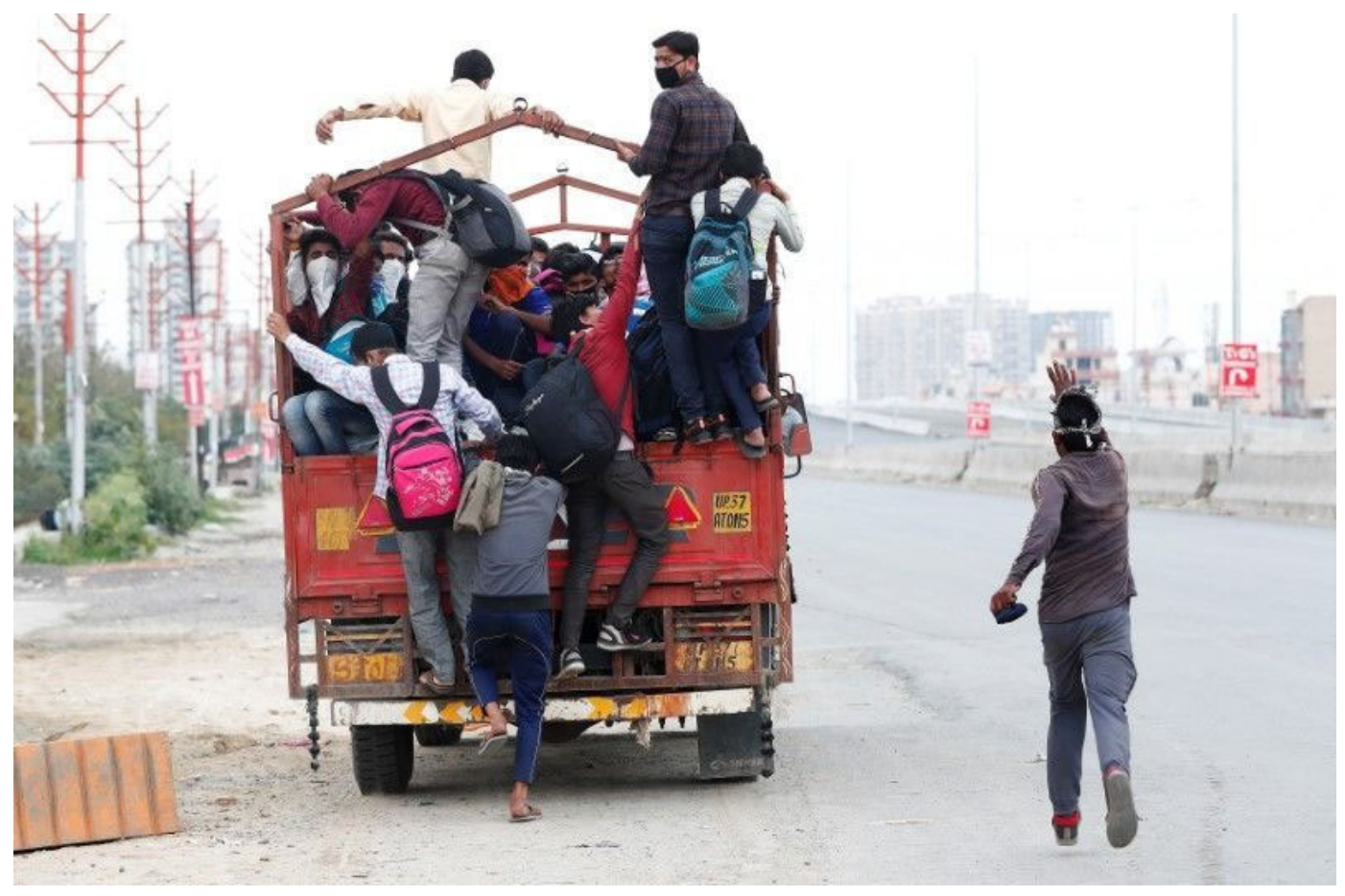

Figure 2. Migrant workers try to board a truck while another runs behind Photo: Adnan Abidi | REUTERS

Witnessing the catastrophe that was being unfolded in the country, the Union Home Ministry urged the state governments to provide immediate relief such as food and shelter to their migrant workers with the help of civil society and to curtail their movement across states. Civil society organisations and state authorities started delivering food to the fleeing migrants and those stranded within the cities and extended welfare schemes such as community kitchens. States like Kerala started labelling migrant workers as guests to mitigate the stigma and to make the workers feel safer in their host city. Kerala alone accounted for $69 \%$ of the overall shelters in the country during the period according to the report handed over to the Supreme court of India by the Union Government (Ramani, 2020). But according to Jan Sahas, '62 percent of workers did not have any information about emergency welfare measures provided by the government and 37 percent did not know how to access the existing schemes' (Jan Sahas, 2020, p. 3).

The scale of the crisis was evident in Uttar Pradesh and the National Capital Region (NCR) in North India. With the increasing risk for the population and faced with heavy criticism, the government of Delhi and state government of Uttar Pradesh started 
providing buses to transport the fleeing migrants. But the ratio of buses to migrants were insufficient. This decision saw thousands of migrants queuing, maintaining little to no physical distancing, and desperately trying to access the few buses to travel back to their homes. The Union Home ministry later in an affidavit to the Supreme court of India claimed news about the buses were fake media reports, contrary to the tweets by Chief Minister of Uttar Pradesh and Delhi's Deputy Chief minister and Transport minister, when criticism was drawn regarding the handling of the bus provision (Singh \& Anand, 2020). Protests were witnessed across India by migrant workers demanding public transportation to chart them back to their villages. In Mumbai protests broke out when migrant workers gathered near Bandra Railway station after fake news was reported about possible trains.

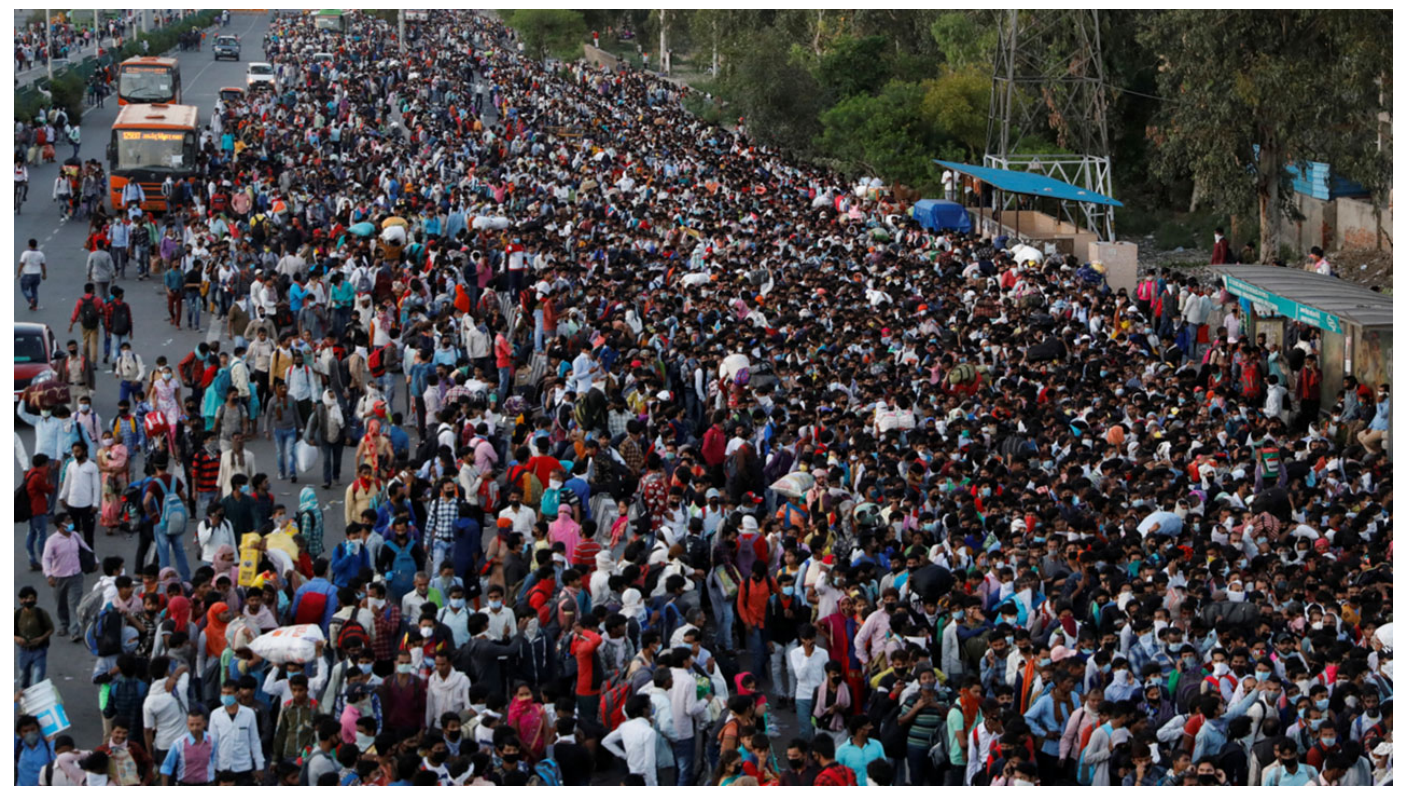

Figure 3. Migrants queue to access the buses made available to shuttle them back home, in Ghaziabad. Photo: Anushree Fadnavis | REUTERS

Highways and railway tracks became their guide lanes on their journey by foot towards home. This mode of movement posed high risk of accidents and safety issues. This crisis led to deaths beyond the figures we see of those who died due to the virus. These numbers should also be included in the total death count since they lay bare a systematic failure from the state when addressing the pandemic. One of the accidents that caught the attention of the entire country, due to the scale of its tragedy, is the death of 16 migrant workers from a group of twenty who were run over by a goods train when resting assuming all trains have stopped functioning, while they were following the rail tracks back to their villages.

The severity of the issue and with national and international criticism towards the Central government's handling of the lockdown, special trains called Shramik trains were arranged for the fleeing migrant workers from May $\mathrm{I}^{\text {st }}$ with partial easing of lockdown. This decision saw joyous migrants queuing with police supervision and adequate precautions being undertaken before entering the train such as sanitising, 
thermal screening and quarantine facilities when reaching their villages. But many migrants were still stranded with no information regarding these trains.

Table I: Deaths due to Lockdown (last updated on 04/07/2020) - Conservative figure

Source: Data compiled by Thejesh G.N., Kanika Sharma and Aman;

https://thejeshgn.com/projects/covid I9-india/non-virus-deaths/

\begin{tabular}{l|c}
\hline Reason & N. of deaths \\
\hline Exhaustion (walking, standing in queues) & 47 \\
\hline Starvation and financial distress & 216 \\
\hline Police brutality or state violence & 12 \\
\hline $\begin{array}{l}\text { Lack of medical care and attention to vulnerable groups (elderly or } \\
\text { patients) }\end{array}$ & 77 \\
\hline Death by crimes associated with lockdown (not communal) & 18 \\
\hline Accidents due to walking or during migration & 209 \\
\hline Alcohol withdrawal-related deaths and suicides & 49 \\
\hline $\begin{array}{l}\text { Suicides due to fear of infection, loneliness, and lack of freedom of } \\
\text { movement }\end{array}$ & 133 \\
\hline Death by Shramik Trains & 96 \\
\hline Deaths in quarantine centres & 49 \\
\hline Unclassified (unable to categorize, need more details) & 65 \\
\hline
\end{tabular}

The government and local authorities faced severe backlash when it came to attention that the migrant workers, who were already cash deprived, were being asked to pay for their tickets, at times at higher prices. The backlash from opposition, activists and citizens across India against the insensitive decision compelled the government to declare that the government will cover workers' travel expense. Karnataka High Court directed the state government to cover the cost of travel of migrant workers and the Supreme Court of India issued a delayed order on May $28^{\text {th }}$ stating that the migrants shouldn't be made to pay for their tickets (SWAN, 2020, PII-I2). But as reports emerged, many workers still had to pay for their tickets despite the government assurance (ibid, P 20). Within the period of 4 months a total of 462 I Shramik trains were operated carrying around 6,319,000 migrants to their home states. An estimated 97 people died while travelling on these trains due to pre-existing medical conditions as informed by the Minister of Railways Piyush Goyal. But according to a zonal officer in the railways, "Heat, exhaustion and thirst are among the primary issues faced by the passengers on board these trains' (SWAN, 2020, PI5). Several reports emerged about the deplorable conditions on these trains with passengers being given limited provision of food and water (Ameen, 2020). Another factor that was not taken into consideration was the lack of transportation and other adequate provisions to reach the railway stations in the main cities to access the Shramik trains. Many migrant workers who had registered via government portal and police stations for the Shramik trains were incapable of reaching the trains on time because of the distance they had to travel to the main city to access these trains. Similarly, the means of transportation to travel 
back to their villages and towns once they have reached their home state was not considered. These legs of the journey were again taken under precarious conditions by the migrant workers (ibid, pp. 29-50).

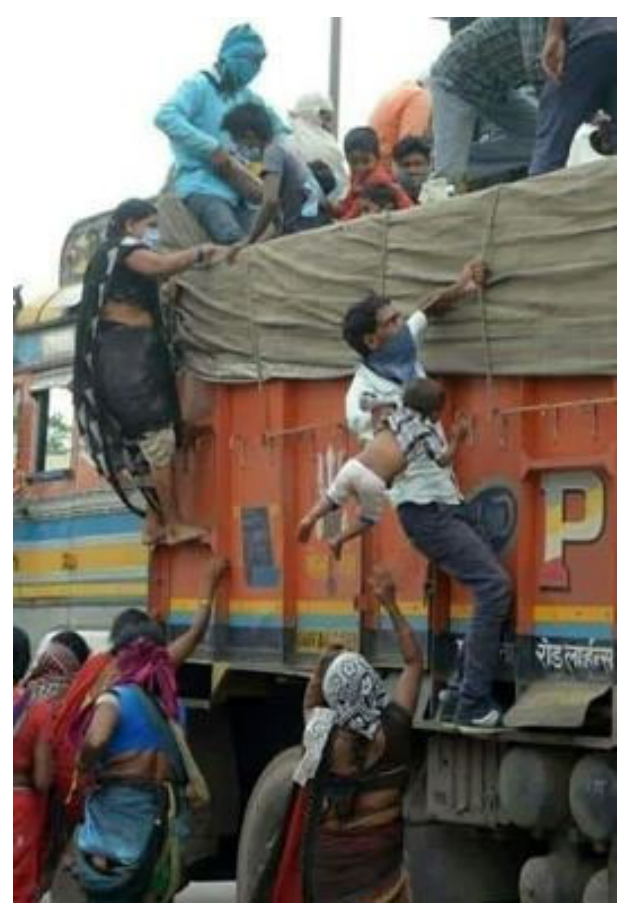

Figure 4: Stranded migrants in Raipur hitching rides on trucks calling it their 'only option' to avoid the long walk home Photo: NDTV

The migrant workers' crisis has now become a glaring failure of the Indian state apparatus. This crisis has shed light into the apathy with which they were treated in the national discourse. 'The extensive media coverage of the mass movement of migrants, media reports along with concerns by activists and public has ensured that the centre and state move towards direct action now in addressing this issue' (Jan Sahas, 2020, P 25). On 14th May 2020, the government took the first step in allocating a sum of Rs 1000 crore for care of migrant workers from the Prime Minister's Citizen Assistance and Relief in Emergency Situations Fund (PM-CARES). This amount was allotted to the different states to be used for accommodation, food, medical and transportation assistance. But as academic and activist Yogendra Yadav highlights, there is little to no proper policy addressing the migrant workers and mention of their circumstances is usually absent in the Prime minister's addresses to the nation. Despite the measures announced during this period such as low cost rental accommodation for returning migrant workers, National food security act, One Nation One ration (to make the food rations available for all citizens in every city and village in India) and the National Rural Employment Guarantee Act (NREGA), the immediate need of the migrants, that of free public transport, was not addressed (Narayan, 2020). State governments of Uttar Pradesh, Madhya Pradesh and some other states have started to roll back labour protection laws as a means to boost investors and businesses, putting the migrant workers in an even more precarious position. This decision is being met with criticism as repealing labour laws is seen as violation of fundamental human rights and would 
allow for slave like working conditions. As stated in the Stranded Workers Action Network (SWAN) report titled 'To leave or not to leave'.

'Given the array of shocks and risks that the working poor, and women in particular, are exposed to, the need for a comprehensive evaluation and implementation of social protection measures made by the erstwhile National Commission for the Enterprises in the Unorganised Sector (NCEUS) is critical. The International Covenant on Economic, Social and Cultural Rights (ICESCR), 1966, is an international human rights treaty in which India is a signatory. Anchoring on human dignity, ICESCR lays out the need for certain fundamental rights and freedoms for everybody. It is, therefore, high time that we reconfigure our society and strengthen our laws based on these principles instead of the proposed dilution of labour laws.'

(Swan, 2020, p. 52)

In Karnataka the state government attempted to halt shramik trains from operating on behalf of real estate and industry leaders who required the migrant labour force. The decision was revoked due to wide scale opposition. The government during the parliament session in September denied having data regarding the migrant deaths and loss of livelihood incurred by the migrant workers due to the lockdown imposed, as they didn't collect the data (Saha, 2020). This is once again a systematic erasure of the value of a migrant worker's life, who we claim are the backbone of the country. This situation urges us to make the states and the central government accountable and to protect migrant workers in the long-term planning of cities. Our structure is not capable of handling the mass reverse exodus, with people moving back to rural areas with poor employment rates. There maybe two ways we can try addressing the situation. One is to make the city equipped and safe as quickly as possible with dedicated central and state government policies set to mitigate the crisis, , up to date data regarding migration and safety nets to accommodate and protect the migrant workers. A structural realignment and reforms are required to make 'Cities for All' by strengthening and challenging the local levels of administration (Agarwala and Vaidya, 2020). Or, this might be our opportunity to rethink the development of rural areas, to take on a radical restructuring of their economy to make them self-sufficient. Whichever the answer is, this pandemic has shown migration without adequate social security is a humanitarian crisis that needs to be addressed at a national level and should pave the means to protect the migrant workers now and in any future natural disasters. 


\section{References}

Agarwal, K. (2020) 'Not Just the Aurangabad Accident, 383 People Have Died Due to the Punitive Lockdown', The Wire, I0th May. Available at: https://thewire.in/rights/migrant-workers-noncoronavirus-lockdown-deaths

Agarwala, P. \& Vaidya, H., (2020) 'Can COVID-1 9 fill the void of City Governance for Urban Transformation?', UN India, 7th May. Available at: Can COVID-19 Fill the Void of City Governance for Urban Transformation? - UN India

Ameen, F. (2020) 'No food and water aboard Shramik special trains ', The Telegraph India, 23rd May. Available at: Coronavirus: No food and water aboard Shramik Special trains - Telegraph India

Anand, J. \& Singh, V. (2020) 'Corononavirus lockdowm| Union Home Ministry blames 'fake news' for migrant workers gathering at bus stations', The Hindu, 06th June. Available at: Coronavirus lockdown | Union Home Ministry blames 'fake news' for migrant workers gathering at bus stations - The Hindu

Biswas, S. (2020) 'Coronavirus: India's pandemic lockdown turns into a human tragedy', BBC, 30th April. Available at: https://www.bbc.com/news/world-asia-india-52086274

Chatterjee, P. (2020) 'The Pandemic Exposes India's Apathy Toward Migrant Workers', The Atlantic, 12th April. Available at: https://www.theatlantic.com/ideas/archive/2020/04/the-pandemicexposes-indias-two-worlds/609838/

Dharker, A. (2020) 'COVID-I 9 has made migrant workers' plight, state apathy visible', The Indian Express, 25th May. Available at: Covid-19 has made migrant workers' plight, state apathy visible | The Indian Express

Gettleman, J., Raj, S. \& Kumar, H. (2020) 'As India Reopens, Deadly Accidents Break Out', The New York Times, 8th May. Available at: https://www.nytimes.com/2020/05/08/world/asia/indialeak-train-reopen.html

Jan Sahas. (2020) 'Voices of the Invisible Citizens', Jan Sahas, New Delhi, April. Available at: https://ruralindiaonline.org/library/resource/voices-of-the-invisible-citizens/

Kumar, N. \& Das, R. (2020) 'Noida's migrant worker exodus is more about their notions of 'home' than coronavirus: Study', The Print, I st April. Available at : https://theprint.in/opinion/noidasmigrant-worker-exodus-more-notions-of-home/392290/

Kumar, N. \& Das, R. (2020) 'Chronic crisis: Migrant workers and India's COVID - 19 lockdown', LSE South Asia Centre, 8th April. Available at: https://blogs.Ise.ac.uk/southasia/2020/04/08/chronic-crisis-migrant-workers-and-indias-covid19-lockdown/ 
Not all Lockdowns are Created Equal

Narayan, S. (2020) 'The invisible ghosts who walk will haunt India for years to come', The Wire, 19th May. Available at: The Invisible Ghosts Who Walk Will Haunt India for Years to Come (thewire.in)

Niti Aayog (2018) 'Strategy for New India @ 75', Niti Aayog, New Delhi, November

Padmanabhan, C. (2020) 'Will Migrants' Lockdown Experiences Become the Debris of History That Reaches the Sky?', The Wire, I I th May. Available at: https://thewire.in/rights/india-lockdownmigrants-deaths

Ramani, S. (2020) 'Coronavirus package | Will migrant workers benefit from the Centre's measures? ', The Hindu, 17th May. Available at: Coronavirus package | Will migrant workers benefit from the Centre's measures? - The Hindu

Ratho, A. \& Bhowmick, S. (2020) 'East to West: India's migrant crisis looms large during COVID-19', Observer Research Foundation, I0th April. Available at: https://www.orfonline.org/expert-speak/east-west-india-migrant-crisis-looms-large-duringcovid I $9-64880 /$

Saha, P. (2020) 'No data on deaths, job losses among migrant workers during lockdown:government', India Today, 14th September. Available at: No data on deaths, job losses among migrant workers during lockdown: Government - India News (indiatoday.in)

Sharma, S. \& Khanna, S. (2020) 'India's migrant workers face long walk home amid coronavirus lockdown', Reuters, 26th March. Available at: India's migrant workers face long walk home amid coronavirus lockdown | Reuters

Singh, S. (2020) 'Explained: Indian migrants, across India', The Indian Express, 6th April. Available at: Explained: Indian migrants, across India | Explained News, The Indian Express

SWAN. (2020) 'To leave or not to leave? Lockdown, Migrant Workers and their journey home', Stranded Workers Action Network(SWAN), $5^{\text {th }}$ June. Available at: To leave or not to leave - SWAN 2020 (strandedworkers.in)

Tanvi, N,S. (2020) 'The face of exploitation', The Hindu, I I th May. Available at: The face of exploitation - The Hindu

World Bank (2020) 'COVID-1 9 Crisis Through a Migration Lens', Migration and Development Brief 32, April

I I 4 | The Journal of Public Space, 5(3), 2020 | ISSN 2206-9658

City Space Architecture / UN-Habitat 